\title{
CurRent Concepts Review Reducing Perioperative Blood Loss and Allogeneic Blood Transfusion in Patients Undergoing Major Spine Surgery
}

\author{
Eva Y.W. Tse, MBChB, Wai Y. Cheung, MBBS, FRCS, FHKOS, FHKAM(Ortho Surg), \\ Kwok F.J. Ng, MBChB, MD, FANZCA, FHKCA, FHKAM(Anaes), MBA, and \\ Keith D.K. Luk, MBBS, MCh(Ortho), FRACS, FRCSEd, FRCS(Glas), FHKOS, FHKAM(Ortho Surg) \\ Investigation performed at the Department of Anaesthesiology and the Department of Orthopaedics and Traumatology, \\ The University of Hong Kong, Hong Kong SAR, China
}

> At present, individual techniques, including intraoperative acute normovolemic hemodilution, use of tranexamic acid, use of intrathecal morphine, proper positioning, and modification of operative techniques, seem most promising for reducing perioperative blood loss and allogeneic blood transfusion in patients undergoing major spine surgery.

> Other techniques including preoperative autologous predonation; mandatory discontinuation of use of antiplatelet agents; intraoperative and postoperative red-blood-cell salvage; use of aprotinin, epsilon-aminocaproic acid, recombinant factor VIla, or desmopressin; induced hypotension; avoidance of hypothermia; and minimally invasive operative techniques require additional studies to either establish their effectiveness or address safety considerations.

Blood loss is a major issue in spine surgery. With increased awareness of the potential hazards of allogeneic blood transfusion, reducing blood loss during major spine procedures becomes more important. Achievement of this goal requires a concerted effort from spine surgeons and anesthesiologists alike. While a prior review of techniques to decrease blood loss during major spine surgery has been published', newer techniques and concepts continue to evolve rapidly in this field. The present article provides a comprehensive review of the most recent techniques and concepts in this area, which we have divided into those applicable in the preoperative, intraoperative, and postoperative periods (Table I).

\section{Preoperative Period}

Optimal Management of Concurrent Medications

That May Affect Intraoperative Bleeding

Antiplatelet medications such as aspirin and clopidogrel are commonly prescribed for patients with cardiovascular or cere- brovascular disease. Either continuation or discontinuation of these medications preoperatively may be associated with risks. In a meta-analysis of 500 patients receiving aspirin on a chronic basis, Burger et al. ${ }^{2}$ showed that withdrawal from low-dose aspirin was the preceding event in $10.2 \%$ of patients who developed acute myocardial infarction, stroke, or peripheral arterial occlusion, or who died of cardiac complications, during non-cardiac surgery. However, continuation of aspirin use increased the rate of intraoperative bleeding complications by a factor of 1.5, although without a concomitant increase in perioperative morbidity or mortality except after intracranial surgery and transurethral prostatectomy. Hence, Burger et al. recommended discontinuing aspirin use only if the risk of bleeding outweighed the cardiovascular risks of aspirin withdrawal. Chassot et al. reviewed the results of perioperative antiplatelet therapy in patients at risk for myocardial infarction and recommended an algorithm approach for making the

Disclosure: None of the authors received payments or services, either directly or indirectly (i.e., via his or her institution), from a third party in support of any aspect of this work. None of the authors, or their institution(s), have had any financial relationship, in the thirty-six months prior to submission of this work, with any entity in the biomedical arena that could be perceived to influence or have the potential to influence what is written in this work. Also, no author has had any other relationships, or has engaged in any other activities, that could be perceived to influence or have the potential to influence what is written in this work. The complete Disclosures of Potential Conflicts of Interest submitted by the authors of this work are available with the online version of this article at jbjs.org. 


\section{TABLE I Outline of Techniques, and Their Strengths and Weaknesses, to Reduce Perioperative Blood Loss and Allogeneic Blood} Transfusion in Patients Undergoing Major Spine Surgery

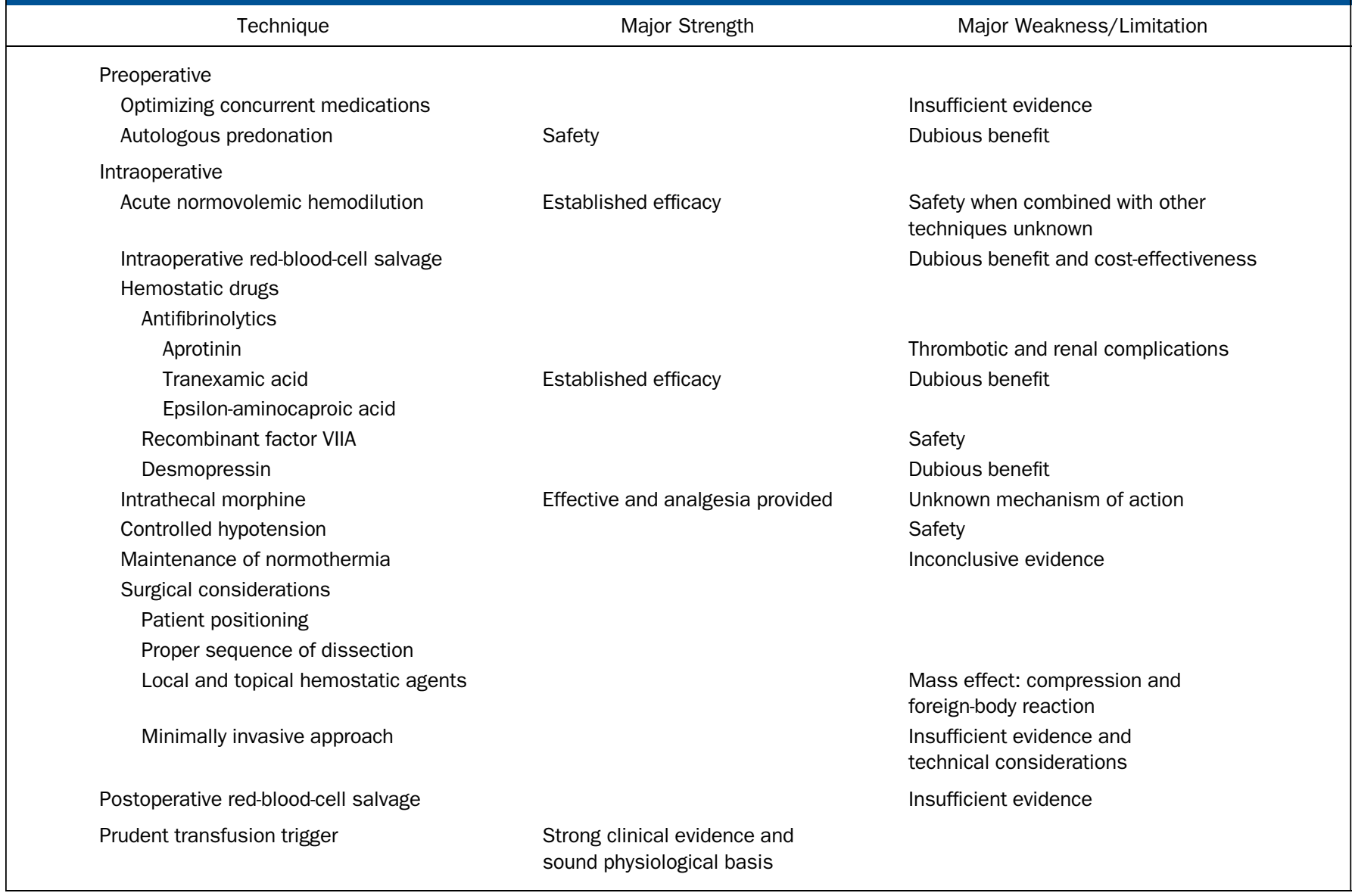

decision to continue or discontinue use of these drugs ${ }^{3}$. The algorithm took into account the indication for treatment as well as the type of operation. Discontinuation of aspirin use seven days before intracranial surgery was recommended by Chassot et al. However, Chassot et al. recommended performing the spine procedure without interruption of aspirin use when a patient had had a recent myocardial infarction (less than six weeks before the operation) or insertion of a drug-eluting stent less than twelve months previously. Spine surgery was not specifically addressed in the review by Burger et al.

The effect of low-dose aspirin on bleeding during spine surgery has never been studied well. In a recent survey in which neurosurgeons at 142 neurosurgical facilities were successfully interviewed ${ }^{4}$, two-thirds (ninety-four) of the respondents believed aspirin to be a risk factor for hemorrhagic complications associated with spine procedures, and more than half of the neurosurgeons interviewed reported having personal experience of such problems during spine operations. Moreover, a subgroup of specialists who performed more than 600 spine operations per year thought that use of low-dose aspirin should be discontinued seven days before the operation. In the absence of more solid evidence, these opinions are not unreasonable.
Additional studies are needed to provide more evidence on this subject.

Continuation of clopidogrel use by patients undergoing non-cardiac surgery was shown to be associated with substantial ;bleeding. ${ }^{3}$. Although no increase in morbidity and mortality (except for patients treated with intracranial surgery) was found, surgical bleeding and transfusion rates were increased by $50 \%$.

Many orthopaedic patients may be taking nonselective cyclooxygenase (COX) inhibitors (nonsteroidal anti-inflammatory drugs [NSAIDs]) preoperatively for their anti-inflammatory and analgesic effects. These drugs have antiplatelet effects similar to those of aspirin. However, because they are reversible COX inhibitors, their antiplatelet effects disappear usually over twentyfour hours after discontinuation ${ }^{5}$. Recently, the platelet function analyzer PFA-100 was found to be useful in monitoring the degree of platelet inhibition in these patients preoperatively.

\section{Autologous Predonation}

Autologous blood predonation is an established technique that has been reported to be safe and effective, decreasing the need for allogeneic blood transfusion in lumbar spine fusion and scoliosis surgery ${ }^{7,8}$. However, in a retrospective study of 676 
The Journal of Bone \& Joint Surgery $\cdot$ Jbjs.org Volume 93-A · Number 13·July 6, 2011
Reducing Perioperative Blood Loss and Allogeneic Blood Transfusion in Major Spine Surgery patients who had undergone elective spine surgery, Brookfield et al. reported that patients who had predonated blood had blood loss similar to that of patients who had not predonated and had more blood replacement ${ }^{9}$. Moreover, there was no significant difference in allogeneic blood transfusion rates between the two groups.

A critical issue in the success of a predonation program is the patient's rate of erythropoiesis. Use of erythropoietin in conjunction with an iron sulfate supplement can increase the number of autologous blood units that the patient can donate ${ }^{10}$.

\section{Intraoperative Period}

\section{Acute Normovolemic Hemodilution}

Acute normovolemic hemodilution is widely used in spine surgery and has had good results in terms of decreasing the allogeneic blood transfusion requirements of patients treated with spine fusion $^{11,12}$ as well as in those treated with scoliosis surgery ${ }^{13,14}$. Epstein et al. ${ }^{15}$ reported that allogeneic blood transfusion was avoided by fifty-two of sixty-eight patients treated with acute normovolemic hemodilution during lumbar spine fusion with instrumentation. The author of an earlier review article ${ }^{16}$ concluded that acute normovolemic hemodilution was both safe and effective in decreasing the need for allogeneic blood transfusion, especially in patients undergoing multilevel lumbar laminectomies with or without fusions. One additional benefit is that acute hemodilution of up to $30 \%$ may induce a mild hypercoagulable state ${ }^{17,18}$, which may help to reduce intraoperative bleeding.

The volume of blood available for collection is determined by the individual patient's preoperative blood volume, hematocrit, and targeted hematocrit (estimated blood volume $\times$ [baseline hematocrit - targeted hematocrit]/average hematocrit) ${ }^{8}$. There may be some difficulty with combining this technique with autologous predonation.

\section{Intraoperative Red-Blood-Cell Salvage}

The role of intraoperative red-blood-cell salvage in reducing the need for allogeneic blood transfusion remains controversial. It was reported to be effective in reducing allogeneic blood transfusion in spine laminectomies, fusions, or instrumentation in several retrospective studies ${ }^{19-21}$, a meta-analysis ${ }^{22}$, and a Cochrane review ${ }^{23}$. However, the quality of these studies varies.

A recent retrospective study by Gause et al. ${ }^{24}$ showed that the use of intraoperative red-blood-cell salvage in elective lumbar fusion with instrumentation not only did not decrease the need for blood transfusion, but was also associated with substantially greater blood loss. Although the authors could not explain the apparent paradox, they proposed that perhaps surgeons became less meticulous with hemostasis in the presence of blood salvage. Alternatively, the reinfused salvaged blood might have contained products that interfered with normal coagulation.

Cost is a frequent concern about the use of intraoperative blood salvage. The cost of red-blood-cell salvage has been shown to exceed its benefits in patients undergoing correction for idiopathic scoliosis $^{13}$. When red-blood-cell salvage was compared with acute normovolemic hemodilution, the latter was found to be more cost-effective $^{25}$. It has been estimated that red-blood-cell salvage is cost-effective only if at least two blood units are recovered ${ }^{26}$.

Red-blood-cell salvage is contraindicated for surgical procedures involving a tumor, infection, or application of some topical agents.

\section{Use of Hemostatic Drugs Antifibrinolytics}

Recent meta-analyses supported the usefulness of antifibrinolytics. A meta-analysis in $2009^{27}$ showed that aprotinin and tranexamic acid substantially reduced blood loss in pediatric scoliosis surgery, a finding that was in agreement with that of a Cochrane review in $2008^{28}$. Another meta-analysis in $2008^{29}$ also showed tranexamic acid and epsilon-aminocaproic acid to be effective in reducing blood loss and transfusion requirements, with no substantial morbidity or increased rate of thromboembolic events, in patients undergoing spine surgery.

\section{Aprotinin}

Aprotinin is a potent serine protease inhibitor extracted from bovine lung tissues. It reduces fibrinolysis by inhibiting plasmin activity and has been found to reduce blood loss in cardiac surgery since $1987^{30,31}$.

Aprotinin decreased blood loss and blood transfused in patients undergoing major orthopaedic surgery that was expected to result in blood loss of $>2000 \mathrm{~mL}^{32}$, but its usage in spine surgery showed conflicting results. Previous controlled studies demonstrated a reduction in blood loss and transfusion requirements in adult patients undergoing spine reconstruction surgery ${ }^{33}$ and in children and adolescents undergoing spine surgery with fusions to correct deformity ${ }^{34}$. More recent studies also demonstrated promising results with regard to decreasing blood loss and the need for allogeneic blood transfusion in adults undergoing spine surgery to correct deformity and those undergoing surgery to address neuromuscular scoliosis ${ }^{35,36}$.

However, one randomized prospective study did not show any reduction in blood loss in adolescents undergoing surgery for idiopathic scoliosis ${ }^{37}$. Another study demonstrated a reduction in intraoperative and postoperative blood loss, but not in allogeneic blood transfusion, in patients treated with posterior spine fusion ${ }^{38}$.

Notably, in recent years aprotinin was associated with concerns about increased risks of perioperative myocardial infarction, stroke, renal dysfunction ${ }^{39}$, and anaphylaxis. A recent large-scale study involving 2331 patients showed that using aprotinin in high-risk cardiac surgery was associated with higher rates of mortality from cardiogenic shock, right ventricular failure, congestive heart failure, or myocardial infarction ${ }^{40}$. Similarly, aprotinin use in adults undergoing spine surgery to correct deformity may be associated with an increased risk of acute renal failure and deep venous thrombosis ${ }^{41}$. The U.S. Food and Drug Administration (FDA) suspended use, except for investigational use, of aprotinin in late 2007.

\section{Tranexamic Acid}

Tranexamic acid is a synthetic lysine analogue that inhibits the binding of lysine residues on fibrin to plasmin or plasminogen, 
The Journal of Bone \& Joint Surgery $\cdot$ Jbjs.org Volume 93-A · Number 13 · July 6, 2011
Reducing Perioperative Blood Loss and Allogeneic Blood Transfusion in Major Spine Surgery thus preventing fibrinolysis. It has well-established efficacy in reducing blood loss in knee and hip replacement surgery. In contrast, the efficacy of tranexamic acid in reducing blood loss in spine surgery has only recently been studied.

Shapiro et al. ${ }^{42}$ showed that tranexamic acid significantly reduced $(\mathrm{p}<0.001)$ both intraoperative blood loss and allogeneic blood transfusion requirements in spine fusions for treatment of scoliosis in patients with Duchenne muscular dystrophy. Elwatidy et al. ${ }^{43}$ found that the prophylactic use of high-dose tranexamic acid was an effective, safe, and inexpensive method for reducing blood loss during and after spine operations. Wong et $\mathrm{al}^{4}{ }^{44}$ reported significantly reduced $(\mathrm{p}=$ 0.017 ) perioperative blood loss during elective posterior thoracic or lumbar spine fusion with instrumentation in adults. Grant et al. ${ }^{45}$ showed that the efficacy of tranexamic acid is dose-dependent. The use of a higher dose (a $20-\mathrm{mg} / \mathrm{kg}$ loading dose followed by $10-\mathrm{mg} / \mathrm{kg} / \mathrm{hr}$ intravenous infusion) for patients with idiopathic scoliosis resulted in a 50\% reduction in transfusion requirements compared with those associated with a lower dose (10-mg/kg loading dose followed by a $1-\mathrm{mg} / \mathrm{kg} / \mathrm{hr}$ intravenous infusion).

\section{Epsilon-Aminocaproic Acid}

Epsilon-aminocaproic acid is another lysine analogue with antifibrinolytic action. There are conflicting data regarding the efficacy of epsilon-aminocaproic acid in reducing blood loss during spine surgery. Florentino-Pineda et al. ${ }^{46}$ found a decrease in blood loss and transfusion needs in patients undergoing surgery for idiopathic scoliosis. Recently, Thompson et al. further established the role of epsilon-aminocaproic acid in reducing blood loss and transfusion requirements in patient undergoing anterior or posterior spine fusions for idiopathic scoliosis ${ }^{47}$ and neuromuscular scoliosis ${ }^{47,48}$. However, other studies ${ }^{49-51}$ did not show any benefit of epsilon-aminocaproic acid in major surgery, including orthopaedic procedures.

\section{Recombinant Factor VIIa}

Recombinant factor VIIa improves hemostasis by enhancing thrombin formation on activated platelets. It was approved by the U.S. FDA for use in hemophilic patients with bleeding. Off-label uses have been reported in operative settings such as trauma surgery $y^{52-54}$, neurosurgery $y^{5,56}$, prostatic surgery ${ }^{57}$, cardiac surgery ${ }^{58-61}$, and spine surgery ${ }^{62}$. Two recent studies showed promising results in terms of reducing blood loss and allogeneic blood transfusion during spine surgery. The first was a retrospective case series of adolescents with idiopathic scolio$\operatorname{sis}^{63}$, and the second was a prospective randomized controlled trial $^{64}$. Although the authors of the randomized controlled trial claimed that "no safety concerns were indicated for the use of rFVIIa in patients at all doses tested," the study may be underpowered to address such concerns. Moreover, there was one case of myocardial infarction and one case of ischemic stroke in the group that received recombinant factor VIIa in this study, findings that warrant further investigation.

A retrospective review showed that when 15 to $180 \mu \mathrm{g} / \mathrm{kg}$ of recombinant factor VIIa was administered to patients with bleeding due to a coagulopathy in medical and surgical settings, $80 \%$ (thirty-two of forty) had complete or partial cessation of the bleeding ${ }^{65}$. Another study showed that cessation of bleeding was not significantly different among doses of $<70 \mu \mathrm{g} / \mathrm{kg}, 70$ to $90 \mu \mathrm{g} / \mathrm{kg}$, and $>90 \mu \mathrm{g} / \mathrm{kg}^{66}$. Thus, the current recommended dose of recombinant factor VIIa is about 70 to $90 \mu \mathrm{g} / \mathrm{kg}$.

We do not advocate the off-label use of any medication, including recombinant factor VIIa. In addition, there are two major concerns about the use of recombinant factor VIIa: thrombotic complications and its cost. The risk of thrombotic events with approved uses of recombinant factor VIIa is ${ }^{10 w^{67}}$, but thrombotic stroke, myocardial infarction, deep vein thrombosis, and mortality have all been reported in association with offlabel use of the drug, including in patients undergoing spine surgery $^{64}$. The cost of a single dose of $90 \mu \mathrm{g} / \mathrm{kg}$ in a $70-\mathrm{kg}$ adult is over $\$ 5000$.

\section{Desmopressin}

Desmopressin, also known as DDAVP, is a synthetic analogue of the antidiuretic hormone vasopressin. It increases the levels of factor VIII and von Willebrand factor and is indicated for use in von Willebrand disease, platelet disorders, or platelet dysfunction in patients with cirrhosis or renal failure ${ }^{68}$. Its use in spine surgery to decrease intraoperative blood loss has been reported, but a definite benefit has not yet been established. A controlled trial ${ }^{69}$ showed desmopressin use to be associated with a decrease in blood loss and transfusion requirements in scoliosis surgery. However, a considerable number of other studies did not show a reduction of blood loss in patients undergoing surgery for idiopathic, congenital, or neuromuscular scoliosis ${ }^{70-72}$. The authors of one study reported that there was no evidence to support the routine use of desmopressin in orthopaedic surgery ${ }^{50}$.

\section{Use of Intrathecal Morphine}

A meta-analysis by Guay ${ }^{73}$ showed that neuraxial blocks (epidural or spinal) in addition to general anesthesia or as the sole anesthetic technique decrease intraoperative and postoperative blood loss as well as the need for transfusion associated with different types of operative interventions, including spine fusion. The use of local anesthetics in neuraxial blocks causes hypotension, which is generally believed to cause the reduction in blood loss associated with neuraxial blocks. The use of localanesthetic-based neuraxial blocks in major spine surgery may be undesirable because of the associated hypotension, which may aggravate hemodynamic instability should major bleeding occur, as well as because of concerns about hypotension in a patient in a prone position. In addition, the use of local anesthetic neuraxial blocks may make neurological assessment more difficult postoperatively.

Unlike local anesthetics, neuraxial opioids such as intrathecal morphine do not interfere with neurological assessment and they cause less hypotension. Intrathecal morphine reduces blood loss in major spine surgery, in addition to providing satisfactory pain relief. In at least three prospective randomized trials, intrathecal morphine administered before 
The Journal of Bone \& Joint Surgery · Jbjs.org Volume 93-A · Number 13·July 6, 2011
Reducing Perioperative Blood Loss and Allogeneic Blood Transfusion in Major Spine Surgery operations substantially reduced intraoperative blood loss. Goodarzi $^{74}$ used $0.02 \mathrm{mg} / \mathrm{kg}$ of intrathecal morphine together with $50 \mu \mathrm{g}$ of sufentanil and observed a $50 \%$ reduction in blood loss. Gall et al. ${ }^{75}$ used 2 and $5 \mu \mathrm{g} / \mathrm{kg}$ of morphine and observed a $65 \%$ reduction in blood loss in the $5-\mu \mathrm{g} / \mathrm{kg}$ group. Eschertzhuber et al. ${ }^{76}$ showed that intrathecal morphine (either 5 or $15 \mu \mathrm{g} / \mathrm{kg}$, plus $1 \mu \mathrm{g} / \mathrm{kg}$ of sufentanil) reduced blood loss by $48 \%$. Despite the consistent efficacy, the mechanism for this benefit remains elusive.

\section{Use of Controlled Hypotension}

Controlled hypotension has been used for decades in orthopaedic surgery to limit blood loss. Decreased blood extravasation and local wound blood flow with lower arterial blood pressure is the generally perceived benefit of this technique. However, since epidural venous plexus pressure ${ }^{77}$ and intraosseous pressure ${ }^{78}$ are more important determinants of blood loss in spine surgery in which bone decortications are involved, and both are independent of arterial blood pressure, the exact mechanism and value of this technique are still unknown.

The main concern with the use of controlled hypotension is its potential complications. The most worrisome is postoperative loss of vision, which is estimated to occur in $0.09 \%$ of patients (three of 3351 patients) undergoing spine surgery in the prone position ${ }^{79}$. A long operative time, a prone position with direct pressure to the eyes, massive blood loss, anemia, and hemodilution are risk factors for loss of vision after spine surgery. Hypotension is frequently observed in patients who have postoperative loss of vision, although a definite association remains to be established ${ }^{80}$. Induced hypotension must be used extremely cautiously in patients undergoing surgery in the prone position.

Low systolic blood pressure can also jeopardize perfusion to end organs, including the spinal cord. Studies have shown changes in the findings of evoked potential monitoring but no increase in the rate of neurological deficits with controlled hypotension ${ }^{81}$. Given the potential adverse effect of induced hypotension on organ perfusion, the safety of induced hypotension, particularly in combination with other techniques that may also affect tissue oxygen delivery such as hemodilution, requires proper evaluation.

\section{Temperature Regulation}

Hypothermia can lead to hemostatic impairment. Michelson et $\mathrm{al}^{82}$ found that the most important factor in the development of hemostatic impairment is cold-induced impairment of platelet function. Impaired enzyme activity in the coagulation cascade plays only a minor role.

Mild hypothermia can increase blood loss and allogeneic blood transfusion requirements during operative treatment. Schmied et al. compared patients who had been randomized to not receive active warming (mean core temperature, $35^{\circ} \mathrm{C}$ ) and those who had been actively warmed (mean core temperature, $36.6^{\circ} \mathrm{C}$ ) during hip arthroplasty and found a $30 \%$ increase in blood loss and a significant increase in blood transfusion requirements $(\mathrm{p}<0.05)$ in the former group ${ }^{83}$. Similarly, Winkler et al. found a $26 \%$ increase in blood loss in patients undergoing hip arthroplasty with a core temperature of $36.1^{\circ} \mathrm{C}$ compared with those aggressively warmed and with a core temperature of $36.5^{\circ} \mathrm{C}^{84}$. The observation that such small differences in core temperature were of importance is substantiated by a recent meta-analysis ${ }^{85}$, which showed that a core temperature difference of $<1^{\circ} \mathrm{C}$ was associated with an average increase in blood loss of $16 \%$ and an average increase in the risk of transfusion of $22 \%$ in all types of surgery, including hip arthroplasty, cardiac surgery, major abdominal surgery, and hysterectomy.

No evidence regarding the use of temperature regulation in spine surgery is available, to our knowledge. Moreover, a retrospective review by Guest et al. ${ }^{86}$ showed that mild hypothermia was not associated with any increase in blood loss during spine surgery, although this was a small study involving only seventy patients. Additional studies are required to confirm and explain this apparent discrepancy between spine surgery and other surgical procedures.

\section{Intraoperative Considerations \\ Patient Positioning}

It is known that epidural veins are connected to the inferior vena cava by a valveless venous system. In the prone position, abdominal pressure increases and causes compression to the vena cava, which in turn increases pressure in the epidural venous circuit and increases intraoperative blood loss. In 1990, Böstman et al. ${ }^{87}$ demonstrated a significant reduction ( $\mathrm{p}<$ 0.001 ) in intraoperative blood loss during lumbar spine surgery in patients who had been placed on a frame in a supported kneeling position with the abdomen free compared with patients lying on conventional bolsters. The investigators postulated that this effect was brought about by a reduction in the inferior vena caval pressure. This postulation was confirmed by Lee et al. ${ }^{77}$. Those investigators studied differences in inferior vena caval pressure between patients positioned in the traditional prone position on a conventional pad and those positioned on a Relton-Hall frame with the abdomen free from compression. They found that vena caval pressure was significantly lower $(\mathrm{p}<0.05)$ in the patients on the Relton-Hall frame. More recently, $\operatorname{Park}^{88}$ found a correlation between reduction in intra-abdominal pressure and reduction in intraoperative blood loss in spine surgery. In their study, patients were randomly assigned to lie on a Wilson frame with narrow or wide pad support. The investigators found that both intra-abdominal pressure $(\mathrm{p}<0.05)$ and intraoperative blood loss $(\mathrm{p}<0.05)$ were significantly lower in the wide-pad-support group, in which the patient's abdomen was free from compression during surgery. Total intraoperative blood loss was also found to be highly correlated with the mean intra-abdominal pressure during surgery.

\section{Operative Techniques}

The skin over the back, particularly over the neck region, is well perfused. Blood oozing from the skin edge is common after a surgical incision. This oozing can be minimized by local skin infiltration of 1:500,000 epinephrine. Nutrient vessels to paraspinal 
The Journal of Bone \& Joint Surgery · Jbjs.org Volume 93-A · Number 13·July 6, 2011
Reducing Perioperative Blood loss and Allogeneic Blood Transfusion in Major Spine Surgery muscles are in close proximity to the vertebrae. Subperiosteal dissection is essential to minimize damage to these vessels and hence to reduce intraoperative bleeding ${ }^{89}$. Taking the proper sequence of intraoperative steps can also help to reduce blood loss. Spine fusions frequently require decortication of the bone surfaces and lead to bone bleeding. Such bleeding can be minimized by performing this part of the procedure last, followed by the immediate creation of a tamponade of the wound with rapid watertight wound closure. Careful operative hemostasis can reduce intraoperative and postoperative blood loss. Soft-tissue bleeding can usually be stopped with thermal coagulation. Bone bleeding can be stopped with a small amount of bone wax. Epidural bleeding can usually be controlled with bipolar diathermy. If the venous pressure is low, applying hydrostatic pressure by just filling the wound with saline solution may help control epidural venous bleeding ${ }^{90}$.

\section{Use of Topical Hemostatic Agents}

Despite all of the above techniques, bleeding can still be difficult to control. Various topical hemostatic agents are available for use in these situations. They can be divided into two broad categories: passive and active. Passive agents act through contact activation and promotion of platelet aggregation. Active agents generate a fibrin clot following activation of the clotting cascade. Collagen-based, cellulose-based, and gelatin-based hemostatic products are examples of passive topical hemostatic agents. The basic mechanism of action is provision of a physical structure that promotes platelet aggregation, leading to clot formation and effective hemostasis ${ }^{91}$. Active agents have biological activity and directly participate at the end of the coagulation cascade to induce the formation of a fibrin clot at the site of bleeding. They include thrombin and combination products containing thrombin and certain passive hemostatic agents $^{92,93}$. All have a rapid onset of action and provide hemostasis within ten minutes in most patients ${ }^{91}$. As these agents are directly involved in the final physiological events of the coagulation cascade and bypass the initial enzymatic steps, their hemostatic action is less susceptible to coagulopathies caused by clotting-factor deficiencies or platelet dysfunction.

Although topical hemostatic agents are effective in stopping bleeding and reducing blood loss, they have potential disadvantages $^{92}$. The expansion of a passive topical hemostatic agent can result in complications, such as the compression of nerves in surrounding tissue against bone or hard tissue with neurological consequences. Any residual product at the site may also potentiate a foreign-body reaction, chronic inflammation, or infection. We recommend that only the minimum amount of hemostatic agent necessary to achieve hemostasis be used and that as much of the agent as possible be removed once hemostasis has been achieved.

\section{Minimally Invasive Spine Surgery}

Intraoperative blood loss can be minimized by the use of less invasive operative approaches, such as paraspinal muscle-splitting, endoscopic, and percutaneous instrumentation techniques. In contrast to midline subperiosteal dissection and muscle retraction to gain access to the spinal canal, micro-endoscopic lumbar discectomy, with a direct approach to the herniated disc fragment under intraoperative fluoroscopic guidance and a musclesplitting technique, has been shown to produce a smaller surgical wound, less postoperative wound pain, and less intraoperative blood loss. Huang et al..$^{94}$ and Ryang et al..$^{95}$ demonstrated that lumbar discectomies performed with a micro-endoscopic technique are associated with a 50\% reduction in intraoperative blood loss compared with that associated with standard open discectomies. Lumbar spine fusion can also be performed with minimally invasive techniques. These include a paraspinal musclesplitting approach and performance of percutaneous instrumentation under fluoroscopic control. Compared with conventional open procedures, which involve wide posterior exposure from the midline to the tips of the transverse processes and freehand application of instrumentation, minimally invasive techniques can markedly reduce intraoperative blood loss. Rodríguez-Vela et al. ${ }^{96}$ compared one-level lumbar spine fusion performed with a minimally invasive technique with that performed with a standard open technique. Intraoperative blood loss was $757 \mathrm{~mL}$ in the group treated with the standard open technique and $318 \mathrm{~mL}$ in the group treated with the mini-open procedure. Park and Ha reported similar findings, with intraoperative blood loss of $738 \mathrm{~mL}$ in a group treated with a standard open procedure compared with $433 \mathrm{~mL}$ in a group treated with a minimally invasive technique $^{97}$. The difference in blood loss between minimally invasive surgery and a conventional open procedure is even greater in multiple-level spine fusions. Anand et al. reported an average intraoperative blood loss of only $260 \mathrm{~mL}$ in their series in which minimally invasive multiple-level percutaneous correction and fusion had been performed for adult lumbar degenerative scoliosis ${ }^{98}$; this compares with a blood loss of 1 to $3 \mathrm{~L}$ with open procedures ${ }^{99}$.

Minimally invasive techniques are not without disadvantages. With the endoscopic approach, operative dissection is performed via a two-dimensional, small visual field. Perceptions of anatomy and depth are more difficult compared with those with open procedures. Furthermore, minimally invasive techniques frequently require special long instruments that are passed through the working portals to gain access to the operative sites. All of these characteristics make minimally invasive surgery technically more demanding and may lead to higher surgical complication rates, especially in inexperienced hands. Nowitzke ${ }^{100}$ reported his early experience with micro-endoscopic discectomy. He estimated that he needed to perform thirty procedures to learn the technique to perform the operation proficiently, and he encountered seven complications, including dural tears and wrong-level surgery.

\section{Postoperative Period}

\section{Postoperative Red-Blood-Cell Salvage}

There have been few studies on postoperative blood salvage after spine surgery ${ }^{20,21,101}$. Because postoperative salvage was combined with other techniques in earlier studies, it was impossible to evaluate the effect of this technique. Sebastián et al. ${ }^{101}$ evaluated 
The Journal of Bone \& Joint Surgery · Jbjs.org Volume 93-A · Number 13·July 6, 2011
Reducing Perioperative Blood loss and Allogeneic Blood Transfusion in Major Spine Surgery postoperative salvage only and found that it reduced the allogeneic blood requirement by $30 \%$. Although the reinfusion of unwashed postoperatively collected blood has been criticized for introducing harmful substances such as cell debris, marrow fat, fibrin, and free hemoglobin, the use of standard $40-\mu \mathrm{m}$ blood filters for infusion of recovered blood has solved this potential problem ${ }^{102-104}$. Unlike intraoperative salvage, postoperative salvage has not been evaluated in terms of its costeffectiveness.

\section{General Considerations}

\section{Indications for Transfusion}

In recent years, there has been a general paradigm shift toward many surgeons and anesthesiologists adopting more restrictive indications for red blood-cell transfusion, although whether this has had any significant impact on the reduction of allogeneic blood usage remains controversial ${ }^{105}$. The proof-ofconcept Canadian Transfusion Requirements in Critical Care (TRICC) study ${ }^{106}$, which compared a more restrictive threshold for transfusion (a hemoglobin level of $7 \mathrm{~g} / \mathrm{dL}$ ) with a more liberal threshold $(10 \mathrm{~g} / \mathrm{dL})$ showed no significant difference in overall mortality between the two groups. The same group of investigators found similar results in children ${ }^{107}$. A recent systematic review ${ }^{108}$ showed that, in forty-two of forty-five studies, the risks of red blood-cell transfusion outweighed the benefits, the risk was neutral in two studies, and the benefits outweighed the risks in a subgroup (elderly patients with an acute myocardial infarction and a hematocrit of $<30 \%$ ) of a single study.

On the basis of the results of these studies and others, evidence-based practice guidelines and recommendation statements on red blood-cell transfusion were developed and have been constantly updated by relevant associations and societies. For instance, the Association of Anaesthetists of Great Britain and Ireland (AAGBI) stated that a hemoglobin concentration of $<7 \mathrm{~g} / \mathrm{dL}$ is a "strong indication for [red-blood-cell] transfusion" while transfusion is not required when the hemoglobin concentration is $>10 \mathrm{~g} / \mathrm{dL}^{109}$. Similarly, the American Society of Anesthesiologists Practice Guidelines recommended that "red blood cells should usually be administered when the hemoglobin level is less than $6 \mathrm{~g} / \mathrm{dl}$ " and "strongly agree that red blood cells are usually unnecessary when the level is more than $10 \mathrm{~g} / \mathrm{dl}$. ." The determination of whether intermediate hemoglobin concentrations (i.e., 6 to $10 \mathrm{~g} / \mathrm{dL}$ ) justify or require red blood-cell transfusion should be based on the patient's risk for complications of inadequate oxygenation. Moreover, the indications for transfusion of autologous red blood cells may be more liberal than those for transfusion of allogeneic red blood cells because the former is associated with less frequent (although still important) risks.

Although the most desirable transfusion threshold for patients undergoing spine surgery has not been specifically studied, the more general guideline of performing a transfusion when the hemoglobin concentration is $<7 \mathrm{~g} / \mathrm{dL}$ and of carefully weighing the risks against the benefits when the hemoglobin concentration is between 7 and $10 \mathrm{~g} / \mathrm{dL}$ should apply to most patients.

\section{Use of Combination of Techniques}

Many of the techniques and concepts discussed above can be conveniently combined in the perioperative period. However, although there have been small-scale studies in which more than one technique was employed ${ }^{13,19,20}$, whether such combinations are desirable has not been properly evaluated and remains unknown. Safety is the most important concern. For instance, the risk factors for postoperative loss of vision when an operation in performed with the patient in the prone position include both hypotension and hemodilution. Therefore, caution should be exercised before combining induced hypotension with a lower tolerance for transfusion. Even when the patient is not in the prone position, it is conceivable that the safety of these techniques individually may not be extrapolated to the situation when the techniques are combined, as tissue oxygen delivery is described by the equation: cardiac output $x$ hemoglobin concentration $\times$ oxygen saturation. Similarly, as autologous predonation may lower preoperative hemoglobin concentration, the advantage of combining this technique with acute intraoperative hemodilution, or the advantage of one over the other, is currently unknown. The marginal benefit of combining different techniques, such as induced hypotension, hemostatic drugs, and intrathecal morphine, is also unknown. If it can be demonstrated that there is little marginal benefit in adding a technique that tends to be associated with more severe complications, such as induced hypotension, then this may indicate a change in current practice. We could not find any clinical studies that addressed these issues. Some of these techniques do seem synergistic when combined. For instance Waters et al. ${ }^{111}$, using mathematical models, showed that the combination of intraoperative red-blood-cell salvage and acute normovolemic hemodilution would allow more patients to avoid allogeneic blood transfusion than would use of one or the other individual technique alone.

Numerous techniques to reduce perioperative blood loss and allogeneic blood transfusion during major spine surgery have been investigated. In particular, many new studies have provided data since the review by Szpalski et al. ${ }^{1}$ (see Appendix). The effectiveness of many techniques remains to be proven by large-scale randomized controlled trials. In particular, there is a paucity of studies evaluating the safety and marginal benefit of combining different techniques. Individually, intraoperative acute normovolemic hemodilution, use of tranexamic acid, use of intrathecal morphine, proper positioning, and modification of operative techniques seem most promising. On the other hand, additional studies are required to establish either the effectiveness or the safety of preoperative autologous predonation; mandatory discontinuation of use of antiplatelet agents; intraoperative and postoperative blood salvage; use of aprotinin, epsilonaminocaproic acid, recombinant factor VIIa, or desmopressin; induced hypotension; avoidance of hypothermia; and minimally invasive operative techniques.

\section{Appendix}

eA A table showing an evaluation of the latest studies eA (published after 2004) on reducing perioperative blood 
The Journal of Bone \& Joint Surgery $\cdot$ JBjS. org Volume 93-A · Number $13 \cdot$ July 6, 2011
Reducing Perioperative Blood loss and Allogeneic Blood Transfusion in Major Spine Surgery loss and allogeneic blood transfusion in patients undergoing major spine surgery is available with the online version of this article at jbjs.org.
Wai Y. Cheung, MBBS, FRCS, FHKOS, FHKAM(Ortho Surg) Keith D.K. Luk, MBBS, MCh(Ortho), FRACS, FRCSEd, FRCS(Glas), FHKOS, FHKAM(Ortho Surg)

Department of Orthopaedics and Traumatology,

The University of Hong Kong, 5/F Professorial Block, Queen Mary Hospital, Hong Kong SAR, China

Kwok F.J. Ng, MBChB, MD, FANZCA, FHKCA, FHKAM(Anaes), MBA Department of Anaesthesiology, The University of Hong Kong, Room 424, Block K, Queen Mary Hospital, Hong Kong SAR, China. E-mail address: jkfng@hku.hk
Department of Anesthesiology,

F2, Queen Mary Hospital, Pokfulam,

Hong Kong SAR, China

\section{References}

1. Szpalski M, Gunzburg R, Sztern B. An overview of blood-sparing techniques used in spine surgery during the perioperative period. Eur Spine J. 2004;13 Suppl 1: S18-S27.

2. Burger W, Chemnitius JM, KneissI GD, Rücker G. Low-dose aspirin for secondary cardiovascular prevention - cardiovascular risks after its perioperative withdrawal versus bleeding risks with its continuation - review and meta-analysis. J Intern Med. 2005;257:399-414

3. Chassot PG, Delabays A, Spahn DR. Perioperative antiplatelet therapy: the case for continuing therapy in patients at risk of myocardial infarction. Br J Anaesth. 2007; 99:316-28.

4. Korinth MC, Gilsbach JM, Weinzierl MR. Low-dose aspirin before spinal surgery: results of a survey among neurosurgeons in Germany. Eur Spine J. 2007;16:365-72.

5. Goldenberg NA, Jacobson L, Manco-Johnson MJ. Brief communication: duration of platelet dysfunction after a 7-day course of ibuprofen. Ann Intern Med. 2005;142: 506-9.

6. Ng KF, Lawmin JC, Tsang SF, Tang WM, Chiu KY. Value of a single preoperative PFA-100 measurement in assessing the risk of bleeding in patients taking cyclooxygenase inhibitors and undergoing total knee replacement. Br J Anaesth. 2009;102: $779-84$.

7. Lo KS, Chow BF, Chan HT, Gunawardene S, Luk KD. An autologous blood donation program for paediatric scoliosis patients in Hong Kong. Anaesth Intensive Care. 2002;30:775-81.

8. Oga M, Ikuta $\mathrm{H}$, Sugioka $\mathrm{Y}$. The use of autologous blood in the surgical treatment of spinal disorders. Spine (Phila Pa 1976). 1992;17:1381-5.

9. Brookfield KF, Brown MD, Henriques SM, Buttacavoli FA, Seitz AP. Allogeneic transfusion after predonation of blood for elective spine surgery. Clin Orthop Relat Res. 2008;466:1949-53.

10. Goodnough LT, Rudnick S, Price TH, Ballas SK, Collins ML, Crowley JP, Kosmin M, Kruskall MS, Lenes BA, Menitove JE, Silberstein LE, Smith KJ, Wallas CH, Abels $\mathrm{R}$, Von Tress M. Increased preoperative collection of autologous blood with recombinant human erythropoietin therapy. N Engl J Med. 1989;321:1163-8.

11. Hur SR, Huizenga BA, Major M. Acute normovolemic hemodilution combined with hypotensive anesthesia and other techniques to avoid homologous transfusion in spinal fusion surgery. Spine (Phila Pa 1976). 1992;17:867-73.

12. Messmer K. Hemodilution. Surg Clin North Am. 1975;55:659-78.

13. Copley LA, Richards BS, Safavi FZ, Newton PO. Hemodilution as a method to reduce transfusion requirements in adolescent spine fusion surgery. Spine (Phila Pa 1976). 1999;24:219-24.

14. Du Toit $G$, Relton JE, Gillespie R. Acute haemodilutional autotransfusion in the surgical management of scoliosis. J Bone Joint Surg Br. 1978;60:178-80.

15. Epstein NE, Peller A, Korsh J, DeCrosta D, Boutros A, Schmigelski C, Greco J. Impact of intraoperative normovolemic hemodilution on transfusion requirements for 68 patients undergoing lumbar laminectomies with instrumented posterolateral fusion. Spine. 2006;31:2227-31.

16. Epstein NE. Bloodless spinal surgery: a review of the normovolemic hemodilution technique. Surg Neurol. 2008;70:614-8.

17. Ng KF, Lam CC, Chan LC. In vivo effect of haemodilution with saline on coagulation: a randomized controlled trial. Br J Anaesth. 2002;88:475-80.

18. Ng KF, Lo JW. The development of hypercoagulability state, as measured by thrombelastography, associated with intraoperative surgical blood loss. Anaesth Intensive Care. 1996;24:20-5.

19. Lennon RL, Hosking MP, Gray JR, Klassen RA, Popovsky MA, Warner MA. The effects of intraoperative blood salvage and induced hypotension on transfusion requirements during spinal surgical procedures. Mayo Clin Proc. 1987;62:1090-4. 20. Mandel RJ, Brown MD, McCollough NC 3rd, Pallares V, Varlotta R. Hypotensive anesthesia and autotransfusion in spinal surgery. Clin Orthop Relat Res. 1981;154: 27-33.

21. Behrman MJ, Keim HA. Perioperative red blood cell salvage in spine surgery. A prospective analysis. Clin Orthop Relat Res. 1992;278:51-7.
22. Huët C, Salmi LR, Fergusson D, Koopman-van Gemert AW, Rubens F, Laupacis A. A meta-analysis of the effectiveness of cell salvage to minimize perioperative allogeneic blood transfusion in cardiac and orthopedic surgery. International Study of Perioperative Transfusion (ISPOT) Investigators. Anesth Analg. 1999;89:861-9.

23. Carless PA, Henry DA, Moxey AJ, O'connell DL, Brown T, Fergusson DA. Cell salvage for minimising perioperative allogeneic blood transfusion. Cochrane Database Syst Rev. 2006;4:CD001888.

24. Gause PR, Siska PA, Westrick ER, Zavatsky J, Irrgang JJ, Kang JD. Efficacy of intraoperative cell saver in decreasing postoperative blood transfusions in instrumented posterior lumbar fusion patients. Spine (Phila Pa 1976). 2008;33:571-5. 25. Shulman G, Solanki DR, Nicodemus CL, Flores IM, Hadjipavlou AG. Audit of autotransfusion in spine surgery. Int Orthop. 1998;22:303-7.

26. Clagett GP, Valentine RJ, Jackson MR, Mathison C, Kakish HB, Bengtson TD. A randomized trial of intraoperative autotransfusion during aortic surgery. J Vasc Surg. 1999;29:22-31.

27. Schouten ES, van de Pol AC, Schouten AN, Turner NM, Jansen NJ, Bollen CW. The effect of aprotinin, tranexamic acid, and aminocaproic acid on blood loss and use of blood products in major pediatric surgery: a meta-analysis. Pediatr Crit Care Med. 2009;10:182-90.

28. Tzortzopoulou A, Cepeda MS, Schumann R, Carr DB. Antifibrinolytic agents for reducing blood loss in scoliosis surgery in children. Cochrane Database Syst Rev. 2008;3:CD006883.

29. Gill JB, Chin Y, Levin A, Feng D. The use of antifibrinolytic agents in spine surgery. A meta-analysis. J Bone Joint Surg Am. 2008;90:2399-407.

30. Royston D, Bidstrup BP, Taylor KM, Sapsford RN. Effect of aprotinin on need for blood transfusion after repeat open-heart surgery. Lancet. 1987;2:1289-91.

31. van Oeveren W, Jansen NJ, Bidstrup BP, Royston D, Westaby S, Neuhof $\mathrm{H}$, Wildevuur CR. Effects of aprotinin on hemostatic mechanisms during cardiopulmonary bypass. Ann Thorac Surg. 1987;44:640-5.

32. Samama CM, Langeron $O$, Rosencher N, Capdevila X, Rouche P, Pegoix M, Bernière J, Coriat $\mathrm{P}$. Aprotinin versus placebo in major orthopedic surgery: a randomized, double-blinded, dose-ranging study. Anesth Analg. 2002;95:287-93. 33. Urban MK, Beckman J, Gordon M, Urquhart B, Boachie-Adjei O. The efficacy of antifibrinolytics in the reduction of blood loss during complex adult reconstructive spine surgery. Spine (Phila Pa 1976). 2001;26:1152-6.

34. Cole JW, Murray DJ, Snider RJ, Bassett GS, Bridwell KH, Lenke LG. Aprotinin reduces blood loss during spinal surgery in children. Spine (Phila Pa 1976). 2003; 28:2482-5.

35. Tayyab NA, Mariller MM, Rivlin M, Berekashvili K, Bitan FD, Casden AM, Kuflik P, Neuwirth MG. Efficacy of aprotinin as a blood conservation technique for adult deformity spinal surgery: a retrospective study. Spine (Phila Pa 1976). 2008;33: 1775-81.

36. Kasimian S, Skaggs DL, Sankar WN, Farlo J, Goodarzi M, Tolo VT. Aprotinin in pediatric neuromuscular scoliosis surgery. Eur Spine J. 2008;17:1671-5.

37. Khoshhal K, Mukhtar I, Clark P, Javvis J, Letts M, Splinter W. Efficacy of aprotinin in reducing blood loss in spinal fusion for idiopathic scoliosis. J Pediatr Orthop. 2003;23:661-4.

38. Lentschener $\mathrm{C}$, Cottin $\mathrm{P}$, Bouaziz H, Mercier FJ, Wolf M, Aljabi Y, Boyer-Neumann $\mathrm{C}$, Benhamou $\mathrm{D}$. Reduction of blood loss and transfusion requirement by aprotinin in posterior lumbar spine fusion. Anesth Analg. 1999;89:590-7.

39. Levy JH. Safety of aprotinin in heparinized and nonheparinized patients. J Cardiothorac Vasc Anesth. 2004;18:38S-42S.

40. Fergusson DA, Hébert PC, Mazer CD, Fremes S, MacAdams C, Murkin JM, Teoh K, Duke PC, Arellano R, Blajchman MA, Bussières JS, Côté D, Karski J, Martineau R, Robblee JA, Rodger M, Wells G, Clinch J, Pretorius R. BART Investigators. A comparison of aprotinin and lysine analogues in high-risk cardiac surgery. $N$ Engl J Med. 2008;358:2319-31.

41. Okubadejo GO, Bridwell KH, Lenke LG, Buchowski JM, Fang DD, Baldus CR, Nielsen $\mathrm{CH}$, Lee CC. Aprotinin may decrease blood loss in complex adult spinal 
The Journal of Bone \& Joint Surgery - jbjs.org Volume 93-A · Number 13·July 6, 2011
Reducing Perioperative Blood Loss and Allogeneic

Blood Transfusion in Major Spine Surgery deformity surgery, but it may also increase the risk of acute renal failure. Spine (Phila Pa 1976). 2007;32:2265-71.

42. Shapiro F, Zurakowski D, Sethna NF. Tranexamic acid diminishes intraoperative blood loss and transfusion in spinal fusions for Duchenne muscular dystrophy scoliosis. Spine (Phila Pa 1976). 2007;32:2278-83.

43. Elwatidy S, Jamjoom Z, Elgamal E, Zakaria A, Turkistani A, El-Dawlatly A. Efficacy and safety of prophylactic large dose of tranexamic acid in spine surgery: a prospective, randomized, double-blind, placebo-controlled study. Spine (Phila Pa 1976). 2008;33:2577-80.

44. Wong J, El Beheiry H, Rampersaud YR, Lewis S, Ahn H, De Silva Y, Abrishami A, Baig N, McBroom RJ, Chung F. Tranexamic acid reduces perioperative blood loss in adult patients having spinal fusion surgery. Anesth Analg. 2008;107:1479-86.

45. Grant JA, Howard J, Luntley J, Harder J, Aleissa S, Parsons D. Perioperative blood transfusion requirements in pediatric scoliosis surgery: the efficacy of tranexamic acid. J Pediatr Orthop. 2009;29:300-4.

46. Florentino-Pineda I, Thompson GH, Poe-Kochert C, Huang RP, Haber LL, Blakemore LC. The effect of Amicar on perioperative blood loss in idiopathic scoliosis: the results of a prospective, randomized double-blind study. Spine (Phila Pa 1976). 2004;29:233-8.

47. Thompson GH, Florentino-Pineda I, Poe-Kochert C, Armstrong DG, Son-Hing JP. The role of Amicar in same-day anterior and posterior spinal fusion for idiopathic scoliosis. Spine (Phila Pa 1976). 2008;33:2237-42.

48. Thompson GH, Florentino-Pineda I, Poe-Kochert C, Armstrong DG, Son-Hing J. Role of Amicar in surgery for neuromuscular scoliosis. Spine (Phila Pa 1976). 2008;33:2623-9.

49. Amar D, Grant FM, Zhang H, Boland PJ, Leung DH, Healey JA. Antifibrinolytic therapy and perioperative blood loss in cancer patients undergoing major orthopedic surgery. Anesthesiology. 2003;98:337-42.

50. Kovesi T, Royston D. Pharmacological approaches to reducing allogeneic blood exposure. Vox Sang. 2003;84:2-10.

51. Erstad BL. Systemic hemostatic medications for reducing surgical blood loss. Ann Pharmacother. 2001;35:925-34.

52. Martinowitz U, Kenet G, Segal E, Luboshitz J, Lubetsky A, Ingerslev J, Lynn M. Recombinant activated factor VII for adjunctive hemorrhage control in trauma. J Trauma. 2001;51:431-9.

53. Grounds M. Recombinant factor VIla (rFVIla) and its use in severe bleeding in surgery and trauma: a review. Blood Rev. 2003;17 Suppl 1:S11-21.

54. Boffard KD, Riou B, Warren B, Choong PI, Rizoli S, Rossaint R, Axelsen M, Kluger Y; NovoSeven Trauma Study Group. Recombinant factor VIla as adjunctive therapy for bleeding control in severely injured trauma patients: two parallel randomized, placebo-controlled, double-blind clinical trials. J Trauma. 2005;59:8-18.

55. Park P, Fewel ME, Garton HJ, Thompson BG, Hoff JT. Recombinant activated factor VII for the rapid correction of coagulopathy in nonhemophilic neurosurgical patients. Neurosurgery. 2003;53:34-9.

56. Karadimov D, Binev $K$, Nachkov $Y$, Platikanov V. Use of activated recombinant Factor VII (NovoSeven) during neurosurgery. J Neurosurg Anesthesiol. 2003;15:330-2. 57. Friederich PW, Henny CP, Messelink EJ, Geerdink MG, Keller T, Kurth KH, Büller HR, Levi M. Effect of recombinant activated factor VII on perioperative blood loss in patients undergoing retropubic prostatectomy: a double-blind placebo-controlled randomised trial. Lancet. 2003;361:201-5.

58. Karkouti K, Beattie WS, Wijeysundera DN, Yau TM, McCluskey SA, Ghannam M, Sutton D, van Rensburg A, Karski J. Recombinant factor VIlla for intractable blood loss after cardiac surgery: a propensity score-matched case-control analysis. Transfusion. 2005;45:26-34.

59. Karkouti K, Yau TM, Riazi S, Dattilo KM, Wasowicz M, Meineri M, McCluskey SA, Wijeysundera DN, van Rensburg A, Beattie WS. Determinants of complications with recombinant factor Vlla for refractory blood loss in cardiac surgery. Can J Anaesth. 2006;53:802-9.

60. McCall P, Story DA, Karalapillai D. Audit of factor Vlla for bleeding resistant to conventional therapy following complex cardiac surgery. Can J Anaesth. 2006;53: 926-33.

61. von Heymann C, Redlich U, Jain U, Kastrup M, Schroeder T, Sander M, Grosse J, Ziemer S, Koscielny J, Konertz WF, Wernecke KD, Spies C. Recombinant activated factor VII for refractory bleeding after cardiac surgery - a retrospective analysis of safety and efficacy. Crit Care Med. 2005;33:2241-6.

62. Tobias JD. Synthetic factor VIla to treat dilutional coagulopathy during posterior spinal fusion in two children. Anesthesiology. 2002;96:1522-5.

63. Kolban M, Balachowska-Kosciolek I, Chmielnicki M. Recombinant coagulation factor VIla-a novel haemostatic agent in scoliosis surgery? Eur Spine J. 2006;15: 944-52.

64. Sachs B, Delacy D, Green J, Graham RS, Ramsay J, Kreisler N, Kruse P, Khutoryansky N, Hu SS. Recombinant activated factor VII in spinal surgery: a multicenter, randomized, double-blind, placebo-controlled, dose-escalation trial. Spine (Phila Pa 1976). 2007;32:2285-93.

65. O'Connell NM, Perry DJ, Hodgson AJ, O'Shaughnessy DF, Laffan MA, Smith OP. Recombinant FVlla in the management of uncontrolled hemorrhage. Transfusion. 2003;43:1711-6.
66. Goodnough LT, Lublin DM, Zhang L, Despotis G, Eby C. Transfusion medicine service policies for recombinant factor VIla administration. Transfusion. 2004;44: 1325-31.

67. Hedner U, Erhardtsen E. Potential role for rFVlla in transfusion medicine. Transfusion. 2002;42:114-24.

68. Mannucci PM. Desmopressin: a nontransfusional form of treatment for congenital and acquired bleeding disorders. Blood. 1988;72:1449-55.

69. Kobrinsky NL, Letts RM, Patel LR, Israels ED, Monson RC, Schwetz N, Cheang MS. 1-Desamino-8-D-arginine vasopressin (desmopressin) decreases operative blood loss in patients having Harrington rod spinal fusion surgery. A randomized, double-blinded, controlled trial. Ann Intern Med. 1987;107:446-50.

70. Alanay A, Acaroglu E, Ozdemir O, Erçelen O, Bulutçu E, Surat A. Effects of deamino-8-D-arginin vasopressin on blood loss and coagulation factors in scoliosis surgery. A double-blind randomized clinical trial. Spine (Phila Pa 1976). 1999;24: 877-82.

71. Guay J, Reinberg C, Poitras B, David M, Mathews S, Lortie L, Rivard GE. A trial of desmopressin to reduce blood loss in patients undergoing spinal fusion for idiopathic scoliosis. Anesth Analg. 1992;75:405-10.

72. Theroux MC, Corddry DH, Tietz AE, Miller F, Peoples JD, Kettrick RG. A study of desmopressin and blood loss during spinal fusion for neuromuscular scoliosis: a randomized, controlled, double-blinded study. Anesthesiology. 1997;87:260-7.

73. Guay J. The effect of neuraxial blocks on surgical blood loss and blood transfusion requirements: a meta-analysis. J Clin Anesth. 2006;18:124-8.

74. Goodarzi M. The advantages of intrathecal opioids for spinal fusion in children. Paediatr Anaesth. 1998;8:131-4.

75. Gall O, Aubineau JV, Bernière J, Desjeux L, Murat I. Analgesic effect of low-dose intrathecal morphine after spinal fusion in children. Anesthesiology. 2001;94:447-52.

76. Eschertzhuber S, Hohlrieder M, Keller C, Oswald E, Kuehbacher G, Innerhofer P. Comparison of high- and low-dose intrathecal morphine for spinal fusion in children. Br J Anaesth. 2008;100:538-43.

77. Lee TC, Yang LC, Chen HJ. Effect of patient position and hypotensive anesthesia on inferior vena caval pressure. Spine (Phila Pa 1976). 1998;23:941-7.

78. Kakiuchi M. Intraoperative blood loss during cervical laminoplasty correlates with the vertebral intraosseous pressure. J Bone Joint Surg Br. 2002;84:518-20.

79. Roth S, Barach P. Postoperative visual loss: still no answers-yet. Anesthesiology. 2001;95:575-7.

80. Lee LA, Roth S, Posner KL, Cheney FW, Caplan RA, Newman NJ, Domino KB. The American Society of Anesthesiologists Postoperative Visual Loss Registry: analysis of 93 spine surgery cases with postoperative visual loss. Anesthesiology. 2006; 105:652-9.

81. Grundy BL, Nash CL Jr, Brown RH. Deliberate hypotension for spinal fusion: prospective randomized study with evoked potential monitoring. Can Anaesth Soc J. 1982;29:452-62.

82. Michelson AD, MacGregor $H$, Barnard MR, Kestin AS, Rohrer MJ, Valeri CR. Reversible inhibition of human platelet activation by hypothermia in vivo and in vitro. Thromb Haemost. 1994; 71:633-40.

83. Schmied H, Kurz A, Sessler DI, Kozek S, Reiter A. Mild hypothermia increases blood loss and transfusion requirements during total hip arthroplasty. Lancet. 1996;347:289-92.

84. Winkler M, Akça O, Birkenberg B, Hetz H, Scheck T, Arkiliç CF, Kabon B, Marker E, Grübl A, Czepan R, Greher M, Goll V, Gottsauner-Wolf F, Kurz A, Sessler DI. Aggressive warming reduces blood loss during hip arthroplasty. Anesth Analg. 2000;91:978-84.

85. Rajagopalan S, Mascha E, Na J, Sessler DI. The effects of mild perioperative hypothermia on blood loss and transfusion requirement. Anesthesiology. 2008; 108:71-7.

86. Guest JD, Vanni S, Silbert L. Mild hypothermia, blood loss and complications in elective spinal surgery. Spine J. 2004;4:130-7.

87. Böstman O, Hyrkäs J, Hirvensalo E, Kallio E. Blood loss, operating time, and positioning of the patient in lumbar disc surgery. Spine (Phila Pa 1976). 1990; 15:360-3.

88. Park CK. The effect of patient positioning on intraabdominal pressure and blood loss in spinal surgery. Anesth Analg. 2000;91:552-7.

89. Gardocki RJ. Spinal anatomy and surgical approaches. In: Canale ST, Beaty JH, editors. Campbell's operative orthopaedics. St. Louis: Mosby; 2008.

90. Menovsky T, De Ridder D. Simple intraoperative technique for hemostasis of cervical venous bleeding. Neurosurgery. 2008;62:0NS442-0NS444.

91. Schonauer C, Tessitore E, Barbagallo G, Albanese V, Moraci A. The use of local agents: bone wax, gelatin, collagen, oxidized cellulose. Eur Spine J. 2004;13 Suppl 1:S89-S96.

92. Samudrala S. Topical hemostatic agents in surgery: a surgeon's perspective. AORN J. 2008;88:S2-11.

93. Renkens KL Jr, Payner TD, Leipzig TJ, Feuer H, Morone MA, Koers JM, Lawson $\mathrm{KJ}$, Lentz R, Shuey H Jr, Conaway GL, Andersson GB, An HS, Hickey M, Rondinone JF, Shargill NS. A multicenter, prospective, randomized trial evaluating a new hemostatic agent for spinal surgery. Spine (Phila Pa 1976). 2001;26:1645-50. 
The Journal of Bone \& Joint Surgery $\cdot$ Jbjs.org Volume 93-A • Number 13·July 6, 2011
Reducing Perioperative Blood loss and Allogeneic

Blood Transfusion in Major Spine Surgery
94. Huang TJ, Hsu RW, Li YY, Cheng CC. Less systemic cytokine response in patients following microendoscopic versus open lumbar discectomy. J Orthop Res. 2005;23:406-11.

95. Ryang YM, Oertel MF, Mayfrank L, Gilsbach JM, Rohde V. Standard open microdiscectomy versus minimal access trocar microdiscectomy: results of a prospective randomized study. Neurosurgery. 2008;62:174-82.

96. Rodríguez-Vela J, Lobo-Escolar A, Joven-Aliaga E, Herrera A, Vicente J, Suñén E, Loste A, Tabuenca A. Perioperative and short-term advantages of mini-open approach for lumbar spinal fusion. Eur Spine J. 2009;18:1194-201.

97. Park Y, Ha JW. Comparison of one-level posterior lumbar interbody fusion performed with a minimally invasive approach or a traditional open approach. Spine (Phila Pa 1976). 2007;32:537-43.

98. Anand N, Baron EM, Thaiyananthan G, Khalsa K, Goldstein TB. Minimally invasive multilevel percutaneous correction and fusion for adult lumbar degenerative scoliosis: a technique and feasibility study. J Spinal Disord Tech. 2008;21:459-67.

99. Hu SS. Blood loss in adult spinal surgery. Eur Spine J. 2004;13 Suppl 1:S3-5. 100. Nowitzke AM. Assessment of the learning curve for lumbar microendoscopic discectomy. Neurosurgery. 2005;56:755-62.

101. Sebastián C, Romero R, Olalla E, Ferrer C, García-Vallejo JJ, Muñoz M. Postoperative blood salvage and reinfusion in spinal surgery: blood quality, effectiveness and impact on patient blood parameters. Eur Spine J. 2000;9:458-65.

102. Semkiw LB, Schurman DJ, Goodman SB, Woolson ST. Postoperative blood salvage using the Cell Saver after total joint arthroplasty. J Bone Joint Surg Am. 1989;71:823-7.

103. Martin JW, Whiteside LA, Milliano MT, Reedy ME. Postoperative blood retrieval and transfusion in cementless total knee arthroplasty. J Arthroplasty. 1992;7:205-10.
104. Blevins FT, Shaw B, Valeri CR, Kasser J, Hall J. Reinfusion of shed blood after orthopaedic procedures in children and adolescents. J Bone Joint Surg Am. 1993; 75:363-71.

105. Pham JC, Catlett CL, Berenholtz SM, Haut ER. Change in use of allogeneic red blood cell transfusions among surgical patients. J Am Coll Surg. 2008;207:352-9. 106. Hébert PC, Wells G, Blajchman MA, Marshall J, Martin C, Pagliarello G, Tweeddale M, Schweitzer I, Yetisir E. A multicenter, randomized, controlled clinical trial of transfusion requirements in critical care. Transfusion Requirements in Critical Care Investigators, Canadian Critical Care Trials Group. N Engl J Med. 1999;340: 409-17.

107. Lacroix J, Hébert PC, Hutchison JS, Hume HA, Tucci M, Ducruet T, Gauvin F, Collet JP, Toledano BJ, Robillard P, Joffe A, Biarent D, Meert K, Peters MJ; TRIPICU Investigators; Canadian Critical Care Trials Group; Pediatric Acute Lung Injury Sepsis Investigators Network. Transfusion strategies for patients in pediatric intensive care units. N EngI J Med. 2007;356:1609-19.

108. Marik PE, Corwin HL. Efficacy of red blood cell transfusion in the critically ill: a systematic review of the literature. Crit Care Med. 2008;36:2667-74.

109. Blood transfusion and the anaesthetists: red cell transfusion 2. London: The Association of Anaesthetists of Great Britain and Ireland; 2008.

110. American Society of Anesthesiologists Task Force on Perioperative Blood Transfusion and Adjuvant Therapies. Practice guidelines for perioperative blood transfusion and adjuvant therapies: an updated report by the American Society of Anesthesiologists Task Force on Perioperative Blood Transfusion and Adjuvant Therapies. Anesthesiology. 2006;105:198-208.

111. Waters JH, Lee JS, Karafa MT. A mathematical model of cell salvage compared and combined with normovolemic hemodilution. Transfusion. 2004;44:1412-6. 